had founded the Analytical Society at Cambridge, and in 1816 had translated Lacroix's "Traité élémentaire du calcul différentiel et du calcul intégral ", thus ably furthering the movement begun by Woodhouse. It was the combined efforts of these four which paved the way for what has been called "the golden age of mathematics and physies at Cambridge". But, by 1828 , Babbage was too deeply engrossed in his calculating machine to devote much time to the duties of a professor, and though he was sensible of the honour conferred upon him, "the only honour", he wrote, "I ever received in my own country ", he contented himself with performing his duties as an examiner. As such he exerted considerable influence, and among the winners of Smith's prize examined by him was William Cavendish, afterwards Duke of Devonshire, chancellor of the University, and the founder of the Cavendish Laboratory.
Babbage held office for eleven years, when he was succeeded by Dr. Joshua King (1798-1857), who from 1832 until 1857 was president of Queens' College. By this time the new school of Cambridge mathematicians included many who were destined to become famous, and during the ten years Dr. King held the Lucasian chair, among the names of the senior wranglers and Smith's prize-winners were those of Ellis, Cayley, Adams, Todhunter, Kelvin, and Stokes, the last of whom in 1849, at the age of thirty, was chosen to succeed Dr. King. On the work of Sir George Gabriel Stokes (1819-1903), the immediate predecessor of Sir Joseph Larmor, it is unnecessary to dwell. During the fifty-four years of his tenure of the chair, he re-established the fame of the office once held by Barrow and Newton, and on the occasion of his scientific jubilee he was hailed as "the Newton of the nineteenth century".

\title{
Centenary of The British Medical Association*
}

$\mathrm{T}$ HE British Medical Association, which is celebrating the centenary of its foundation at its annual meetings in London on July 21-29, is fortunate in having secured a chronicler worthy of the occasion in the person of Mr. Muirhead Little, who is not only a distinguished orthopædic surgeon but is also a well-known and accomplished writer on medical history. His work contains a very full and well-written description of the history of the British Medical Association and its multifarious activities during the last hundred years, together with an account of the leading personalities connected therewith.

Mr. Muirhead Little begins with a sketch of the medical profession in 1832, a year memorable not only for the foundation of the Provincial Medical and Surgical Association, as the British Medical Association was first called, but also for the first epidemic of Asiatic cholera in England, the Anatomy Act, and the First Reform Bill. In the absence of statistical information, the sciences of epidemiology and public health did not then exist, and indeed, until the passing of the Registration Act in 1836, there were no national statistics to justify any trustworthy conclusions. The profession as a whole was not organised, for there was no hard and fast line between the qualified and unqualified practitioner, and it was not until the Medical Act of 1858 , which was almost entirely the work of the Association, that the great body of practitioners first received official recognition of their existence, and their importance to the State was acknowledged. The average medical practitioner in 1832 was a man of little culture or education, and there seems to have been ample justification for the unattractive picture of the contemporary medical student drawn by Dickens in "The Pickwick Papers" and by Thackeray in "Pendennis".

Dr. Charles Hastings, on the other hand, the

\footnotetext{
* History of the British Medical Association, ]832-1932. Complled by Ernest Muirhead Little. Pp. vili $+342+29$ plates. (London: British Medical Association, 1932.)
}

No. 3273 , VoL. 130] founder of the Association, who was knighted in 1850 , was a man of considerable abilities, some originality of mind, and great industry. At the early age of thirty-four years, he became the leading physician in Worcester, as well as being an eminent naturalist. In $\mathbf{1 8 2 8}$ he founded the Midland Medical and Surgical Reporter and Topographical and Statistical Journal, which came to an end in 1832, being succeeded in 1840 by the Provincial Medical and Surgical Journal, the organ of the Association, which during the period $1832-40$ had published only an annual volume of Transactions. It was not until 1856 that the Association, which had hitherto been known as the Provincial Medical and Surgical Association, received its present name, while its organ, which had been renamed the Association Medical Journal in 1853, was given its present title of the British Medical Journal at the beginning of 1857 .

The scientific work of the Association, of which Mr. Muirhead Little gives a very full description, has formed an important part of its activities since its foundation. This work includes the discussion of scientific topics distributed over fourteen to twenty sections at its annual meetings; the dissemination of information in the British Medical Journal and the special journals, the Archives of Disease in Childhood and the Journal of Neurology and Psychopathology; the appointment from time to time of special committees to consider particular aspects of medical science; the arrangement of collective investigations throughout the profession; the award of scholarships, grants, and prizes; and the organisation of lectures, both among members of the profession and the lay public. Moreover, the local units, of which there are several hundreds, devote a great part of their energy to the consideration of scientific questions.

The work carried out by special scientific com. mittees of the Association during the last fifty years includes reports on chloroform, the action of various drugs, the prevention of ophthalmia neonatorum, 
the early recognition of uterine cancer, the treatment of fractures, the question of rheumatic heart disease in childhood, maternity and child welfare work, tests for drunkenness, the eausation of puerperal morbidity and mortality, psychoanalysis and mental deficiency. The subjects chosen for collective investigation have been chloroform, pneumonia, chorea, rheumatism, diphtheria, puerperal fever, the incidence of cancer and the history of its after-treatment.

As regards the work of the local units, it is noteworthy that whereas previously the formulation of a medico-political policy occupied most of their attention, of recent years they have devoted most of their energies to the consideration of scientific and clinical matters.

An important part in the scientific work of the Association is played by the library originally started by Mr. Ernest Hart, a former editor of the British Medical Journal, who made a nucleus collection of books from those sent him for review Until fourteen years ago the library was available only for reference purposes, but since 1918 members have been allowed to borrow books and periodicals.

Although the account of the work of the Association in relation to medical reform, contract practice, and national health insurance may appear somewhat wearisome to the profane and even to some members of the profession not engaged in general practice, it should be borne in mind that it was mainly by the agency of the Association that not only the status and dignity of the profession in
Great Britain were established, but also the interests of the general public were safeguarded.

Among other matters with which Mr. Muirhead Little deals are the work done by the Association on behalf of its members in the Services; its organisation of the profession in the War of 1914-18; its campaign against quackery, in which the publication of "Secret Remedies" and "More Secret Remedies" with their analyses of expensive but worthless nostrums was an important event; schemes of medical benevolence, and medical ethics. Short biographical sketches are included of some of those who devoted their energies to the growth and welfare of the Association, among the most notable being the two eminent surgeons, Sir Victor Horsley and Mr. Edmund Owen; the last two editors of the British Medical Journal, Mr. Ernest Hart and Sir Dawson Williams; Dr. Elizabeth Garrett Anderson, who took a large part in the admission of women to membership of the Association, and Prof. W. E. Dixon, the well-known pharmacologist, whose death we have recently had to deplore.

Mr. Muirhead Little has also included numerous excellent portraits of those who have deserved well of the Association during the last hundred years, including two of the founder, and views of the different buildings occupied by the Association in London and elsewhere. A list of the places of the annual meetings of the Association, with the names of the presidents and other principal officers, forms a useful appendix.

\section{Obituary}

\section{Baron G. J. De FeJÉrváry}

$\mathrm{T}$ HE death at Budapest of Baron de Fejérváry from heart-failure on June 2, after an operation for gall-stones on May 28, too early deprives zoological science of a worker rich in both accomplishment and promise, and his colleagues of a charming and helpful friend. He is mourned above all by a widow and two young children.

Geza Julius Fejérváry de Komlós-Keresztes was born at Budapest on June 25, 1894. On the completion of his university course, he entered the Hungarian National Museum in October 1916, and took up the study of reptiles and amphibians; in 1923 he was made curator of the herpetological section in the department of zoology, a post which he held until his death. Taking the degree of Ph.D. at Budapest in 1917, he became privatdozent for zoogeography at the R. Elizabeth University, Pécs, in 1921, and in February 1930 was appointed professor extraordinarius of zoology in that University. When the International Congress of Zoologists was held at Budapest in 1927, he served as recording secretary and afterwards edited its proceedings, tasks for which he was eminently fitted by his knowledge of the world, his courteous manners, and his facility in languages, which extended beyond the five world-tongues to Russian, Latin, and Greek. His own writings appeared in
Hungarian, German, English, French, and Swiss publications.

While based naturally on his herpetological studies, Fejérváry's contributions to science, with their clearness and precision of statement, gave evidence of a wide philosophical outlook and a keen insight. He was interested in various problems of evolution and particularly in the question of its reversibility; thus in 1920 he published "Observations sur la loi de Dollo,..." (Bull. Soc. Vaud. Sci. Nat.) ; in 1924, "Remarks on Nopcsa's paper on Reversible and Irreversible Evolution" (Arch. Naturgesch:) ; in 1925, "Úber Erscheinungen und Prinzipien der Reversibilität, . . ." (Paläont. Z.); also, in 1929, he criticised Sir Arthur Keith's presidential address to the British Association (Biol. generalis). Among the more important of his systematic and morphological papers were: "Contributions to a monograph on fossil Varanidæ and Megalanidæ" (Ann. Mus. Nat. Hungar., 16; 1918), "Die phyletische Bedeutung des Praehallux und vergleichend-osteologische Notizen über den Anuren-Tarsus " (op. cit., 22 ; 1925), " . . . on the primary and secondary dermal bones of the skull" (Arch. Naturgesch., 90, A ; 1924).

In 1928, Fejérváry organised an expedition to Malta and the neighbouring islands to study questions of zoogeography; his report on this investigation was left incomplete, as also was an

$$
\text { No. } 3273 \text {, Vol. 130] }
$$

